Ks. Norbert WIDOK

\title{
WKŁAD ŚRODOWISKA OPOLSKIEGO W BADANIA NAD ANTYKIEM CHRZEŚCIJAŃSKIM
}

W obecnym, tj. 1999 roku, opolskie środowisko teologiczne obchodzi dwie rocznice związane $\mathrm{z}$ dwiema instytucjami: pierwsza to 50-lecie istnienia Wyższego Seminarium Duchownego (1949-1999), a druga - 5-lecie działalności Wydziału Teologicznego (1994-1999) na Uniwersytecie Opolskim. Należy zaznaczyć, że Wydział Teologiczny został utworzony w Opolu z Filii Katolickiego Uniwersytetu Lubelskiego dużo wcześniej, bo już w 1984 r. i działał do 1994 roku. Jest więc szczególna okazja, by nie tylko na szczeblu lokalnym, ale i ogólnopolskim dokonać podsumowania osiągnięć naukowo-dydaktycznych, także z zakresu antyku chrześcijańskiego. Wyższe Seminarium Duchowne i Wydział Teologiczny (przedtem Filia KUL) są wprawdzie instytucjami posiadającymi odrębne statuty ${ }^{1}$, to jednak od 5 lat, czyli od powstania Wydziału Teologicznego na uniwersytecie, łączy je wspólna kadra wykładowców, którzy niezależnie od swoich zainteresowań publikowali również prace z zakresu antyku chrześcijańskiego i w ten sposób przyczyniali się także do rozwoju dorobku naukowego polskiej patrologii.

Zgodnie z przyjętym w Polsce Ratio studiorum dla seminariów duchownych, wśród przedmiotów wykładanych w trakcie sześcioletnich studiów znajduje się także patrologia. W opolskim seminarium, z powodu bardzo nielicznej kadry profesorskiej, zwłaszcza w początkowym okresie jego istnienia, patrologia była wykładana przez znanych i cenionych profesorów różnych dyscyplin teologicznych. Jej wykładowcami byli: ks. prof. dr Szczepan Szydelski (apologetyk, 19491958), ks. prof. dr Edward Gola (dogmatyk, 1958-1961), ks. dr Alfons Nossol (dogmatyk, 1961-1963), ks. prof. dr Edward Gola (dogmatyk, 1963-65), ks. dr Alfons Nossol (dogmatyk, 1965-1967), ks. prof. dr Edward Gola (dogmatyk, 1967-1973), ks. mgr-lic. Krzysztof Staniecki (dogmatyk, 1973-1978), ks. dr Kazimierz Dola (historyk Kościoła, 1978-1984), ks. mgr-lic. (od 1987 dr) Krzysztof Staniecki (1984-1993) i ks. dr Norbert Widok (patrolog, 1993-). Jak wynika

\footnotetext{
${ }^{1}$ Odnośnie szczegółowych informacji zob. „Rocznik Informacyjny Wydziału Teologicznego Uniwersytetu Opolskiego" 1-2(1994-1996) 23-70 (Stan prawny).
} 
z powyższego wyszczególnienia, ponad 40 lat wykładowcami patrologii byli profesorowie o różnych specjalnościach. Stąd też nie należy oczekiwać, by w tym czasie badania nad starożytnością chrześcijańską prezentowały się bardzo pokaźnie, należy raczej mówić o przekazie wiedzy patrystycznej w ramach działalności dydaktycznej i sporadycznym publikowaniu prac zawierających omówienia zagadnień z antyku chrześcijańskiego, z wyżej wymienionych względów.

$\mathrm{Na}$ niwie zainteresowań patrystycznych w środowisku opolskim wyróżnił się, nieżyjący już ( 1992 r.) ks. dr Albert Warkotsch [= Warkocz], który zwolniony w 1963 r. z obowiązków wykładowcy historii filozofii przez bpa opolskiego Franciszka Jopa, zajął się pracą thumaczeniową. Jej owocem jest przekład wybranych dzieł Maksyma Wyznawcy pt. Dzieła (Antologia życia wewnętrznego, Dialog o życiu wewnętrznym, Księga mitości, Księga oświeconych, Wykład Modlitwy Pańskiej, List o miłości) ${ }^{2}$, poprzedzony bardzo obszernym Wprowadzeniem thumacza (s. 5-72), gdzie opisuje przede wszystkim poglądy filozoficzne Maksyma. Ponadto ks. A. Warkocz, mieszkając przez pewien okres czasu w Niemczech, opublikował książkę, przedstawiającą stosunek Ojców Kościoła do filozofii starożytnej pt. Antike Philosophie im Urteil der Kirchenväter $^{3}$. Natomiast duchowe bogactwo liturgii wschodniej, sięgającej czasów wczesnochrześcijańskich, ukazał wykładowca egzegezy Nowego Testamentu ks. prof. dr hab. Janusz Czerski w książce pt. Boska liturgia św. Jana Chryzostoma. Wprowadzenie liturgiczno-biblijne do liturgii eucharystycznej Kościoła Wschodniego $^{4}$.

W omawianym okresie zostało również opublikowanych przez wykładowców różnych dyscyplin teologicznych kilkanaście artykułów o tematyce patrystycznej. W większości są to artykuły profesorów, którzy jednak nie wykładali patrologii. I tak: ks. prof. dr hab. Wacław Schenk (1982), będąc historykiem liturgii, pozostawił aż sześć artykułów, dotyczących w całości lub w części zagadnień liturgicznych w starożytności: Rok liturgiczny (w starożytności chrześcijańskiej) ${ }^{5}$, Udziat ludu w ofierze Mszy św. Zarys historyczny ${ }^{6}$, Pokuta sakramentalna osób duchownych. Pierwsze wieki chrześcijaństwa ${ }^{7}$, Kult świętych w starożytności chrześcijańskiej do IV wieku ${ }^{8}$, Wptyw ruchu pielgrzymkowego na liturgię rzymska do VIII wieku', Zarys historyczny rozwoju Liturgii Go$d_{z i n^{10}}$. Artykuł o tematyce liturgicznej opublikował także ks. dr Hubert Do-

\footnotetext{
2. Poznań b.r. [1980].

${ }^{3}$ Paderborn 1973.

${ }^{4}$ Opole 1998, ss. 160, Opolska Biblioteka Teologiczna 28.

${ }^{5}$ Wprowadzenie do liturgii, red. F. Blachnicki, Poznań 1967, 432-466.

6 Tamze, 207-238.

${ }^{7}$ RBL 29(1976) 82-85.

${ }^{8}$ W kierunku chrześcijańskiej kultury, red. B. Bejze, Warszawa 1978, 311-328.

${ }^{9}$ RTK 26(1979), z. 4, 129-135.

${ }^{10}$ AK 75(1983), t. 100, 349-357.
} 
biosz: Wspólnotowy charakter sakramentu pokuty w rozwoju historycznym ${ }^{11}$. Problematykę z teologii fundamentalnej, związaną z patrologią, podjął ks. dr Edward Kopeć, który w okresie swej pracy dydaktycznej w WSD w Nysie w latach 1951-1956 opublikował artykuł Pogląd apologetów chrześcijańskich na poznanie Boga ${ }^{12}$, a także jego uczeń ks. dr hab. Tadeusz Dola w artykułach: Zbawienie jako Boża pedagogia w Chrystusie ${ }^{13}$ i Wcielenie jako wydarzenie zbawcze ${ }^{14}$. Temat związany z tajemnicą stworzenia opracował ks. dr hab. Piotr Jaskóła w artykule: Kierunki rozwoju starochrześcijańskiej protologii ${ }^{15}$. Tematykę katechetyczną u św. Augustyna omówił ks. dr Radosław Chałupniak w artykule: „De catechizandis rudibus” św. Augustyna a wspótczesna katecheza szkolna ${ }^{16}$, zaś ks. dr hab. Józef Urban przedstawił szeroko rozumiany dialog religijny w okresie patrystycznym w artykule: Ojcowie Kościoła o możliwości dialogu z innymi religiami ${ }^{17}$. Natomiast spośród wykładowców patrologii problematyką wczesnochrześcijańską zajmował się ks. dr K. Staniecki, który jest autorem kilku artykułów: $U$ źródeł terminologii trynitarnej ${ }^{18}, O$ człowieku $^{19}$, Duch Święty w starożytnym świadectwie Bazylego Wielkiego i nowożytnym Sergiusza Butgakowa ${ }^{20}$.

Ostatni z wyżej wymienionych wykładowców WSD ukończył specjalistyczne studia w zakresie patrologii na Wydziale Teologicznym KUL, w Katedrze Patrologii. Stało się to możliwe dopiero, gdy stanowisko kierownika tej katedry objął w 1984 r. ks. dr hab. Franciszek Drączkowski, co dla patrologii polskiej było momentem przełomowym. Trzeba bowiem dodać, że działalność tej katedry na przestrzeni lat nie wykazywała się stabilnością z tego m.in. powodu, że przez długi okres czasu nie posiadała samodzielnego pracownika ${ }^{21}$. Troska

11 „Studia Teologiczno-Historyczne Śląska Opolskiego” 6(1978) 183-196.

12 RTK 4(1957) z. 2, 97-123.

13 „Studia Teologiczno-Historyczne Śląska Opolskiego” 17(1997) 19-29.

14 „Studia Teologiczno-Historyczne Śląska Opolskiego” 18(1998) 159-170.

15 „Studia Teologiczno-Historyczne Śląska Opolskiego” 16(1996) 45-60.

${ }^{16}$ Człowiek $i$ Kościót $w$ dziejach. Księga pamiątkowa dedykowana Księdzu Profesorowi Kazimierzowi Doli z okazji 65. rocznicy urodzin (Opolska Biblioteka Teologiczna 34), red. J. Kopiec - N. Widok, Opole 1999, 371-378.'

17 Tamże, 399-411.

18 Veritati et caritati. W stużbie teologii i pojednania. Prace dedykowane księdzu biskupowi Alfonsowi Nossolowi z okazji sześćdziesiątej rocznicy urodzin i piętnastolecia święceń biskupich, red. P. Jaskóla, Opole 1992, 91-96.

${ }^{19}$ Ratio et revelatio. Z refleksji filozoficzno-teologicznych. Księga pamiatkowa dedykowana Księdzu Profesorowi Józefowi Herbutowi z okazji 65. rocznicy urodzin (Opolska Biblioteka Teologiczna 30), red. J. Cichoń, Opole 1998, 323-325.

${ }^{20}$ Cztowiek i Kościót $w$ dziejach, dz. cyt., 389-398.

${ }^{21}$ Szczegółowego przedstawienia historii działalności Katedry Patrologii na KUL dokonał F. Drączkowski, Katedra Patrologii w Katolickim Uniwersytecie Lubelskim - rys historyczny, w: Tysiąc imion Chrystusa. Seminarium Patrystyczne KUL 1983-1993, red. J. Pałucki, Lublin 1994, $9-15$. 
ks. F. Drączkowskiego o naukową prężność katedry sprawiła, że po 1984 r., pod jego kierunkiem, tytuł doktora teologii w zakresie patrologii uzyskało 9 doktorantów. Jednym z nich jest ks. Norbert Widok, który po uzyskaniu stopnia doktora w 1991 r. na podstawie pracy pt. Akomodacja misyjna w teorii i praktyce Klemensa Aleksandryjskiego ${ }^{22}$, odbył studia specjalistyczne w Rzymie w latach 1992-1993, uzyskując licencjat na Wydziale Literatury Chrześcijańskiej i Klasycznej przy Papieskim Uniwersytecie Salezjańskim. Od października 1993 r. w WSD przejął wykłady z patrologii, które prowadzi do chwili obecnej.

Bardzo ważną datą dla opolskiego środowiska teologicznego był rok 1994, w którym powstał Uniwersytet Opolski, a przy nim - Wydział Teologiczny z 13 katedrami. Jedną z nich jest Katedra Historii Kościoła i Patrologii, w której oprócz historyków (ks. prof. dr hab. Kazimierz Dola, bp dr hab. Jan Kopiec, ks. dr Franciszek Wolnik, ks. mgr-lic. Rudolf Nieszwiec) zatrudniony w 1994 r. został na stanowisku adiunkta ks. dr Norbert Widok, a w 1997 r. ks. mgr-lic. Brunon Zgraja na stanowisku asystenta.

Ks. Norbert Widok poza opublikowaniem rozprawy doktorskiej jest także redaktorem dwóch prac zbiorowych: Veritatem desiderat anima. Studia patrystyczne z okazji 110 rocznicy urodzin Bertholda Altanera $(1885-1964)^{23}$ i Orbis antiquus. Studia filologiczne $i$ patrystyczne ${ }^{24}$ oraz współredaktorem Księgi pamiątkowej: Człowiek i Kościót w dziejach. Księga pamiq̨tkowa dedykowana Księdzu Profesorowi Kazimierzowi Doli z okazji 65. rocznicy urodzin ${ }^{25}$; ponadto opublikował 20 artykułów o tematyce patrystycznej ${ }^{26}$ i kilka przekła-

22 Opublikowana: Opole 1992, ss. 161.

23 Opole 1995, Opolska Biblioteka Teologiczna 6, ss. 234.

24 Opole 1998, ss. 107.

25 Red. J. Kopiec - N. Widok, Opole 1999, Opolska Biblioteka Teologiczna 34, ss. 637.

${ }^{26}$ Problem akomodacji $w$ katechezie wczesnochrześcijańskiej (Klemens Aleksandryjski). Przegląd bibliografii, VoxP 10(1990) z. 18, 65-73; Cele eklektyzmu Klemensa Aleksandryjskiego, VoxP 11-12(1991-1992) z. 20-23, 361-374; Koncepcja eklektyzmu Klemensa Aleksandryjskiego, „Studia Teologiczno-Historyczne Śląska Opolskiego” 14(1993) 25-37; Quas significationes in Gregorii Nazianzeni orationibus vox „ousia” habeat, „Latinitas” 42(1994) 234-242; Życie i działalność Bertholda Altanera (1885-1964), w: Veritatem desiderat anima, dz. cyt., 11-23; Vocis „ousia” significationes in Gregorii Nazianzeni orationibus, w: Veritatem desiderat anima, dz. cyt., 189-234; Inkulturacja $w$ świetle najnowszych publikacji. Terminologia i pryncypia, „Studia TeologicznoHistoryczne Śląska Opolskiego" 15(1995) 85-109; Akomodacja terminu "trias” - od Teofila z Antiochii do Grzegorza z Nazjanzu, RH 44(1996) z. 3, 185-201; Miłość fundamentem życia moralnego $w$ „Liście do Diogneta”, Ad libertatem in veritate. Księga pamiątkowa dedykowana Księdzu Profesorowi Alojzemu Marcolowi w 65. rocznicę urodzin i 35-lecie pracy naukowej (Opolska Biblioteka Teologiczna 10), red. P. Morciniec, Opole 1996, 197-210; Obecność Ojców Kościoła w „Katechizmie Kościoła Katolickiego”, ,Studia Teologiczno-Historyczne Śląska Opolskiego” 16(1996) 91-101; Akomodacja ewangelizacyjna w „Liście do Diogneta”, „Studia Teologiczno-Historyczne Śląska Opolskiego" 17(1997) 31-37; Ignacy Antiocheński o Eucharystii, w: Ineffabile Eucharistiae donum. Księga pamiątkowa dedykowana Księdzu Biskupowi Alfonsowi Nosso- 
dów $^{27}$. Na Wydziale Teologicznym prowadzi seminarium naukowe z patrologii, będąc promotorem następujących prac magisterskich:

- Andrzej Demitrów, Orygenesowa interpretacja Pisma świętego w rozumieniu Henri de Lubac, Opole 1997;

- Krystian Hajduk, Modlitwa chrześcijańska w ujęciu Tertuliana i Orygenesa na podstawie komentarza do „Ojcze nasz”. Studium porównawcze, Opole 1997;

- Piotr Glinka, Człowiek obrazem Trójcy Świętej na podstawie „De Trinitate" św. Augustyna, Opole 1998;

- Marian Kluczny, Sakrament pokuty w nauczaniu św. Ambrożego na podstawie „De poenitentia”, Opole 1998;

- Grzegorz Dobosz, Miłość jako zasada życia monastycznego wedtug „Regut” św. Bazylego Wielkiego, Opole 1999;

- Tadeusz Jaśkiewicz, Pokuta w nauczaniu Tertuliana, Opole 1999;

- Irena Kunas, Troska pasterska św. Cypriana o praktykę wiary chrześcijan w świetle jego „Listów”, Opole 1999;

- Mariusz Zwarycz, Recepcja „Etyk” Arystotelesa w , Stromatach” Klemensa Aleksandryjskiego, Opole 1999.

Zanim zaczęło funkcjonować seminarium patrystyczne, prace magisterskie dotyczące zagadnień antyku chrześcijańskiego pisano na innych seminariach naukowych. Oto ich szczegółowy wykaz:

1) Seminarium z Historii Kościoła (promotor: ks. prof. dr hab. Kazimierz Dola):

- Piotr Śnigórski, Religijność czasów Grzegorza Wielkiego na podstawie jego listów i „, Księgi Reguty Pasterskiej”, Lublin 1984;

lowi Wielkiemu Kanclerzowi Wydziału Teologicznego Uniwersytetu Opolskiego z okazji 65. rocznicy urodzin oraz 20-lecia święceń biskupich (Opolska Biblioteka Teologiczna 19), red. T. Dola, Opole 1997, 425-434; Inkulturation bei Klemens von Alexandrien, w: ,Studia Patristica”, t. 31, (red. E.A. Livingston), Leuven 1997, 559-568; Teksty patrystyczne w inkunabułach zbiorów biblioteki Wyższego Seminarium Duchownego w Nysie, w: Tradycje kultury antycznej na Śląsku, red. J. Rostropowicz, Opole 1997, 283-288; Ignacy z Antiochii-pisarz judeochrześcijański, w: „Studia Antiquitatis Christianae", t. 13, Warszawa 1998, 50-59; Postawa Grzegorza z Nazjanzu wobec kultury, w: Ojcowie Kościoła wobec filozofii i kultury klasycznej, red. F. Drączkowski - J. Pałucki - M. Szram, Lublin 1998, 137-148; Semantyka terminu „fisis” w literaturze przedchrześcijańskiej. Zarys zagadnienia, w: Orbis antiquus, dz. cyt., 13-20; Przymioty Boga w ,Mowach teologicznych” Grzegorza z Nazjanzu, w: Człowiek i Kościót w dziejach, dz. cyt., 419-424; Imiona i tytuty Boga w „Mowach teologicznych” Grzegorza z Nazjanzu (w druku); Grzegorz z Nazjanzu o Bożym Narodzeniu. Aspekty liturgiczne i chrystologiczne „Mowy 38” (w druku).

${ }^{27}$ Mowa pochwalna Bazylego z Seleucji ku czci św. Szczepana (przekład, wstęp i komentarz), VoxP 9(1989) z. 17, 823-836; Męczeństwo świętego Porfiriusza mima (przeklad, wstęp i komentarz), VoxP 10(1990) z. 19, 885-891; „Mowa V” Euzebiusza z Aleksandrii (przekład, wstęp i komentarz) - w druku. 
- Krzysztof Śmigiera, Życie monastyczne, jego początki, rozwój i ideały w świetle „Historii Kościoła” Sokratesa Scholastyka i Hermiasza Sozomena, Wrocław 1986;

- Józef Kaniut, Życie duchowieństwa w IV wieku w oparciu o „Obowiązi duchownych" św. Ambrożego, Wrocław 1988;

- Krzysztof Dudziński, Obecność Kościoła w życiu publicznym na przykładzie „Obowiąków duchownych” św. Ambrożego, Wrocław 1994 (praca licencjacka, Opole 1997);

- Rudolf Knopp, Dobroczynność w nauczaniu i działalności papieza Grzegorza Wielkiego, Opole 1995;

- Brygida Domowicz, Kobiety chrześcijańskie w „Historii kościelnej” Euzebiusza z Cezarei Palestyńskiej, Opole 1999;

- Małgorzata Nokiel, Świadectwa Ojców Afrykańskich o Eucharystii i sposobie jej sprawowania w okresie prześladowań Kościoła w Imperium Rzymskim, Opole 1999;

2) Seminarium z biblistyki (promotor: ks. prof. dr hab. Janusz Czerski):

- Marian Obruśnik, Interpretacja „Modlitwy Pańskiej” whomiliach św. Grzegorza z Nyssy. Studium z zakresu historii egzegezy, Opole 1995;

3) Seminarium z teologii fundamentalnej (promotor: ks. dr hab. Tadeusz Dola):

- Andrzej Grondowski, Pasterski wymiar postugi kapłańskiej wedtug „Dialogu o kaptaństwie” Jana Chryzostoma, Opole 1996;

Drugim pracownikiem naukowym zatrudnionym w Katedrze Historii Kościoła i Patrologii jest ks. mgr-lic. Brunon Zgraja, który w latach 1991-1997 studiował patrologię również na Wydziale Teologicznym KUL, gdzie w 1995 r. uzyskał licencjat. Obecnie w Katedrze Patrologii KUL, pod kierunkiem ks. dr hab. Jerzego Pałuckiego, finalizuje rozprawę doktorską pt. „Arete” w pismach Klemensa Aleksandryjskiego.

Trzeba też zaznaczyć, że zainteresowania literaturą wczesnochrześcijańską w opolskim środowisku wykraczają poza Wydział Teologiczny; mianowicie dr Gabriela Wcisło, pracownik Instytutu Historii Uniwersytetu Opolskiego, od kilku lat swoje badania koncentruje na twórczości Salwiana z Marsylii, których owocem są następujące artykuły: Salwian z Marsylii-sylwetka twórcy w świetle jego dziet a zwłaszcza listów ${ }^{28}$, Pogańskie wzory chrześcijanina Salwiana $z$ Marsylii $^{29}$, Grecka myśl filozoficzna w utworach Salwiana z Marsylii (w druku).

W kontekście działalności dydaktycznej Wydziału Teologicznego UO należy jeszcze wspomnieć o chwalebnej inicjatywie wykładowców dogmatyki,

28 Studia nad kultura antyczną, red. J. Rostropowicz. Opole 1997, 121-130.

${ }^{29}$ Cztowiek i Kościót w dziejach, dz. cyt., 413-418. 
którzy w ramach ćwiczeń dydaktycznych gruntownie analizują odpowiednio dobrane do wykładanego przedmiotu dzieła Ojców Kościoła. Ks. dr hab. Stanisław Rabiej na ćwiczeniach z trynitologii w roku akademickim 1997/98 prowadził lekturę Listów do Serapiona Atanazego Wielkiego, a w roku akademickim 1998/99 - O Duchu Świętym Bazylego Wielkiego; natomiast ks. dr Andrzej Czaja, w ramach ćwiczeń z eklezjologii w roku akademickim 1998/99, w podobny sposób zapoznawał studentów z Pasterzem Hermasa. Zainteresowanie to należy z pewnością tłumaczyć coraz łatwiejszym dostępem do pisarzy wczesnochrześcijańskich, których dzieła są coraz liczniej tłumaczone na język polski, a także wzrostem świadomości wśród wykładowców teologii o ważności dziedzictwa epoki patrystycznej, jak również wzmożonym zainteresowaniem literaturą patrystyczną studentów.

Opolskie środowisko naukowe było współorganizatorem dwóch sympozjów: Sekcji Patrystycznej w 1989 r. w Nysie i Sekcji Filologicznej w 1998 r. w Opolu i Kamieniu Śląskim. Katedra Historii Kościoła i Patrologii, mimo nielicznej kadry naukowej, jest systematycznie reprezentowana na sympozjach krajowych i zagranicznych. Ponadto współpracuje z nowo powstałym (1995 r.) przy Wydziale Teologicznym czasopismem pt. „Przegląd Piśmiennictwa Teologicznego", w którym zamieszczana jest bieżąca bibliografia literatury patrystycznej w Polsce.

Przedstawiona prezentacja wkładu środowiska opolskich naukowców w badania nad antykiem chrześcijańskim prowadzone w Polsce jest raczej skromna. Niemniej jednak po 1994 r. daje się zauważyć znaczne ożywienie w tej dziedzinie nauki. Dzieje się tak dlatego, że z chwilą powstania Uniwersytetu Opolskiego pojawiły się również przed Katedrą Historii Kościoła i Patrologii nowe możliwości, pozwalające na realizowanie wielu cennych inicjatyw związanych z tą dziedziną wiedzy: organizowanie sympozjów, większa możliwość publikowania, prowadzenie badań własnych i statutowych, współpraca Wydziału Teologicznego z zagranicą.

\title{
OPERA OPPOLIENSIS AMBITUS INDUCTA IN ANTIQUITATEM CHRISTIANAM DISCEPTANDAM
}

\author{
(Argumentum)
}

In ambitu Oppoliensi antiquae litterae christianae in patrologiae praelectionibus in Seminario Maiore (annibus 1949-1999) et in Facultate Theologica Universitatis Oppoliensis (annibus 1994-1999) expromtae sunt. Illo tempore non scripta sunt multa opera, quae ad res litterarum christianarum attinent, quia patrologia a pro- 
fessoribus variorum partium theologiae edocebatur. Qui tamen paucas scripserunt dissertationes et tres libros. Tum demum ab anno 1993 exsistat in Seminario Maiore (ab anno 1994 in Facultate Theologica) professor in patrologia peritus et alter quoque ab anno 1997. Quamobrem ambitus Oppoliensis vehementius versatur in antiquis litteris christianis disceptandis et de his varia scripta foras dat. 